\title{
Grupper i padagogikken: fra indbyrdes undervisning til progressive tiltag og Cooperative Learning
}

\author{
Gerd Christensen* \\ Københavns Universitet
}

\begin{abstract}
SAMMENFATNING
Artiklen giver et indblik i gruppers rolle og funktion i pædagogikken, sådan som det har formet sig i Danmark. Dette sker igennem en genealogisk analyse inspireret af den franske filosof Michel Foucault. Det betyder, at der er fokus på de måder, hvorpå individer subjektiveres, dvs., hvordan de kan blive til subjekter. I artiklen vises det, hvordan grupper har været brugt i pædagogikken fra 1800-tallets indbyrdes undervisning, i den tidlige reformpædagogik fra starten af 1900-tallet, i projektpædagogikken, der havde sin oprindelse i 1970'erne, samt i den nutidige Cooperative Learning. I analysen vises det, hvordan de forskellige tilgange rummer meget forskellige subjektiveringstilbud for såvel elever som lærere: fra underkastelse og disciplin i den indbyrdes undervisning til individualisering i den tidlige reformpædagogik, fleksibilitet og kritisk stillingtagen i projektpædagogikken til internalisering af struktur i CL.
\end{abstract}

Nøgleord: Genealogi; Foucault; subjektivering; gruppearbejde

\begin{abstract}
Small-Groups in Education: From the Bell-Lancaster Method to Progressive Pedagogy and Cooperative Learning

The paper provides an insight into the role and function of groups in education. This is done through a genealogical analysis inspired by the French philosopher Michel Foucault. This means that there is a focus on the ways in which individuals are subjectivated, i.e. how they become subjects. The article shows how groups have been used in the Bell-Lancaster method, in the early reform pedagogy of the early 1900s, in the project pedagogy, which originated in the 1970'es, and in contemporary Cooperative Learning. The analysis shows how the different approaches offer very different opportunities for subjectivation for students and teachers: from subjugation in the Bell-Lancaster method to participation and individualization in the early reform pedagogy, critical attitude and flexibility in the 1970 'es project pedagogy to internalization of structure in CL.
\end{abstract}

Keywords: Genealogy; Foucault; subjectivation; group work

Mottatt: March, 2019; Antatt: November, 2019; Publisert: Mars, 2020

\footnotetext{
^Korrespondanse: Gerd Christensen, epost: gerd@hum.ku.dk

(C) 2020 Gerd Christensen. This is an Open Access article distributed under the terms of the Creative Commons Attribution 4.0 International License (https://creativecommons.org/licenses/by-nc/4.0/), allowing third parties to copy and redistribute the material in any medium or format and to remix, transform, and build upon the material for any purpose, even commercially, provided the original work is properly cited and states its license.

Citation: Gerd Christensen. "Grupper i padagogikken: fra indbyrdes undervisning til progressive tiltag og Cooperative Learning" Nordisk tidsskrift for pedagogikk og kritikk, Vol. 6, 2020, pp. 48-62. http://dx.doi.org/10.23865/ntpk.v6.1635
} 
Grupper og gruppearbejde anvendes i dag i et utal af pædagogiske sammenhænge fra grundskole til ungdomsuddannelser, videregående uddannelser samt kurser af enhver art (Brødslev Olsen, 1995; Sørensen, 1996; Jæger, 2002; Frello, 1996; Kristensen, 1997; Keldorff, 1997; Keldorff \& Nibe, 1999; Granström, 2007; Sanden \& Frederiksen, 1997; Gregersen \& Mikkelsen, 2007; Ulriksen, 1997; Christensen, 2013). Trods den omfattende anvendelse foreligger der relativt lidt forskning om gruppearbejde. Blandt den seneste skandinaviske bør Granström, 2007) og Hammar Chiriac (2003) nævnes. Imidlertid rummer dette ingen overvejelser over, hvorfra de pågældende organisationsformer stammer, endsige hvilke idémæssige præmisser, de bygger på, og hvilke opgør igennem pædagogikkens historie, der har ført os til, hvor vi er i dag.

Hensigten med nærværende artikel er at undersøge gruppernes placering i den danske pædagogik. Dette dog med det forbehold, at de forståelser, der her har manifesteret sig igennem tiden, har været influeret af internationale strømninger, fortrinsvis fra Tyskland, England og de skandinaviske lande. Af afgrænsningsmæssige årsager har det været nødvendigt at fokusere på den danske reception af de pædagogiske ideer.

Artiklen er en genealogisk analyse. Herigennem bliver det muligt at identificere nogle af de antagelser, der knytter sig til grupper i pædagogikken, samt at diskutere, hvorvidt der er elementer, der i dag ligger som en skjult præmis for denne organisationsform og dermed for de subjektiveringstilbud, som bliver deltagerne til del. Når jeg har valgt at anvende begrebet 'grupper i pædagogikken' frem for det oftest anvendte begreb 'gruppearbejde', er det, fordi jeg ønsker at vise, at grupper har været brugt på flere måder, herunder nogle, der er meget forskellige fra det, vi i dag forbinder med 'gruppearbejde'.

Inden for det pædagogiske område har den genealogiske tilgang blandt andet været anvendt af Lynn Fendler, Valerie Walkerdine, Kurt Danziger, Stefan Hermann, Kenneth Petersson og John Krejsler samt af undertegnede i andre sammenhænge (Christensen, 2008; Christensen, 2013; Christensen \& Hamre, 2018; Danziger, 1997; Fendler, 2001; Hermann, 2007; Olsson et al., 2018; Walkerdine, 1984).

\section{Artiklens teoretiske og metodiske forankring}

Inspirationen til artiklens analyser er hentet i Michel Foucaults genealogiske tilgang, der er viderebearbejdet til en egentlig metode af bl.a. Niels Åkerstrøm Andersen og Kasper Villadsen samt undertegnede (Andersen, 1999; Christensen, 2008; Christensen, 2013; Villadsen, 2006). Her defineres genealogi som at skrive nutidshistorie som konstruktion (Andersen, 1999; Christensen, 2008; Christensen, 2013; Villadsen, 2006). Det betyder, at der tages udgangspunkt i et nutidigt fænomen, hvorfra den analytiske proces går bagud i tid. Dette gøres ved at følge kontinuitet, brud og forskydninger i de diskursive bevægelser, der er foregået igennem fænomenets tilbliven (Foucault, 2001, s. 63), og ved at "[...] vise, hvordan forskellige historiske elementer forbindes og transformeres i en nutidig praksis og hermed etablerer bestemte magtrelationer" (Villadsen, 2006, s. 93). 
Der er således tale om en kritisk metode, hvis genstand er subjektiveringen, hvilket vil sige vilkårene for at blive til som et subjekt (Saar, 2002, s. 236). I nærværende tilfælde gælder det en undersøgelse af de forskellige subjektiveringstilbud, som forskellige anvendelser af grupper i pædagogikken har åbnet og lukket igennem tiden. Dette vil blive gjort igennem fire nedslag, der på forskellig vis er markante i gruppernes historie: 1970'ernes projektpædagogik, 1900-tallets reformpædagogik, 1800-tallets indbyrdes undervisning og nutidens Cooperative Learning. Fremstillingen vil springe i tid, sådan at de slægtskaber, der fremtræder, også følges i fremstillingsformen.

Ifølge Foucault udgør materialet for en genealogi den mængde af små og store tekster, der foreligger inden for et vidensfelt (Foucault, 2001). I nærværende tilfælde har teksterne været valgt ud fra, at de har haft betydning for og/eller er evaluerende af praksis, samt at der er gensidige referencer. På denne vis må teksterne anses for at være væsentlige bidrag til den diskursive formation på feltet.

\section{Grupper i padagogikken: Barn af $1970^{\prime}$ erne?}

Ofte tænker vi grupper i pædagogikken som det gruppearbejde, der i de skandinaviske lande tog fart igennem 1970'erne. I Danmark var det i denne periode, det for alvor vandt frem i såvel folkeskolen som på universiteterne, ikke mindst i forbindelse med etableringen af de to ny universitetscentre i Roskilde og Ålborg (RUC i 1972 og AUC (nu AAU) i 1974). Centrene blev etableret som løsning på den tiltagende tilstrømning af studerende til universiteterne samt i forlængelse af ungdomsoprøret i 1968 og den afstandtagen fra 'professorvældet', dette indebar. Sidstnævnte betød også et opgør med de undervisningsformer, der hidtil havde været praktiseret på universiteterne, hvilket vil sige forelæsninger, selvstudium og 'mesterlære'. Til forskel herfra var det pædagogiske omdrejningspunkt på universitetscentrene deltagerstyret, problemorienteret projektarbejde udført af studerende i grupper. En af de betydeligste fortalere for denne organisationsform var Knud Illeris, der som professor i pædagogik var med til at formulere RUC's projektpædagogik (se bl.a. Illeris, 1974; Illeris, 1978).

Interessen for grupper var i disse år ikke forbeholdt pædagogikken, men omfattede en række fænomener fra kollektive boligformer til basisgrupper inden for blandt andet freds-, kvinde- og mandebevægelserne. Grupper var et element blandt flere i en mere generel samfunds-og institutionskritik, der i 1970'erne og i starten af 1980'erne var forankret i de marxistiske strømninger, der var særligt stærke på de danske universiteter og samlet betegnes 'universitetsmarxisme' (Christensen, 2013).

Gruppernes funktion var dels social, dels dannende. Dette gjaldt også i pædagogikken: På den ene side var forventningen til grupperne, at de ville fremme de (ofte uddannelsesfremmede) studerendes tilknytning til studiet (Borgnakke, 1984, s. 18). På den anden side forventede man, at grupperne kunne spare underviserkræfter, fordi de studerende i grupperne 'kunne undervise hinanden' (Christensen, 2013; Hansen, 1997;). Derudover havde man den opfattelse, at grupper kunne 
bidrage med mere end summen af de enkelte medlemmer: "Det kollektive princip er en væsentlig fordel i projektarbejdet, da gruppen og de forenede kræfter er i stand til at producere et mere kvalitativt og kvantitativt arbejde" (Broström, 1974, s. 34-35). Endelig fik grupperne tilskrevet en funktion som forum for politisk dannelse og 'holdningsmæssig indlæring'. Dette tænktes at foregå igennem 'gruppepresmetoden' (Illeris, 1974, s. 39); et fænomen, der øjensynligt blev betragtet som helt legitimt (se bl.a. Jensen m.fl., 1997).

De socialt-faglige begrundelser for grupperne gjorde sig også gældende, efterhånden som gruppearbejde blev mainstream i folkeskolen, der i tiltagende grad var inspireret af universitetscentrenes projektpædagogik (Rasborg, 1968, s. 107). Igennem 1960'erne og 1970'erne blev gruppearbejdet institutionaliseret i en sådan grad, at det, ikke mindst med universitetscentrenes 'grupperum', var blevet 'bygget i beton' (Hansen, 1997). Endelig var det blevet politiseret på en måde, som det skulle tage såvel universitetscentrene som pædagogikken årtier at slippe af med. Arbejdet hermed ses blandt andet i det skift i begrundelserne for grupper i pædagogikken, der fandt sted igennem 1980'erne og 1990'erne. Her blev 1970'ernes henvisninger til gruppernes kollektive og samfundskritiske funktion erstattet af fortællingen om, at gruppearbejdet opøver 'individuelle samarbejdskompetencer' (Christensen, 2013).

Om end referencerne til 1970'ernes pædagogik i dag i nogen grad er skrevet ud af projektpædagogikken, har man stadig en forståelse af, at den opøver sociale kompetencer, der er nødvendige i et samarbejde. Med andre ord subjektivering til fleksibilitet og samarbejde - om end i dag ofte i en individualiseret form. Dertil kommer subjektivering til kritisk stillingtagen (problemorientering) og til at forfølge egne interesser. 1970'ernes kollektivisme lever stadig videre som en myte, der i nogen gad lægger røgslør over de studerendes indbyrdes magtkampe og eksklusionsstrategier overfor medstuderende i grupperne (ibid.). Subjektivering til samarbejde synes således ikke mindst at omfatte at være i stand til at selektere sine medstuderende.

\section{Spontane grupper: Tidlig reformpædagogik}

1970'ernes projektpædagogik tilskrev sig umiddelbar inspiration fra den amerikanske progressivisme fra starten af 1900-tallet, ikke mindst til John Deweys erfaringspædagogik og William Kilpatricks metode til projektarbejde i grupper (Illeris, 1974, s. 86; Kilpatrick, 1918;). I modsætning hertil er der få referencer til den tidlige europæiske reformpædagogik til trods for det åbenlyse slægtskab ${ }^{1}$.

Et af de tidlige reformpædagogiske skoleforsøg blev udført på Vanløse Skole i København i perioden 1924-28 og blev betegnet de frie klasser $i$ Vanløse eller sidenhen Vanløseforsøgene (Henriksen \& Nørgaard, 1983; Nørgaard, 1977). Skoleforsøget blev

${ }^{1}$ Reformpædagogik og progressivisme er begge betegnelser for en bredere pædagogisk bevægelse, der voksede frem omkring 1880'erne i både USA og Europa (Darling \& Nordenbo, 2003). 
iværksat af nogle progressive lærere i samarbejde med engagerede forældre ${ }^{2}$. Alle var de inspireret af reformtankerne i den amerikanske progressivisme, nordisk aktivitetspædagogik samt de nye europæiske skoletanker, der i disse år voksede frem i forlængelse af Ellens Keys indflydelsesrige bog Barnets århundrede (Key, 1902). I forskellige varianter byggede disse tanker på Rousseaus naturalistiske forståelse af barnet som et frit individ, der helst skulle udvikle sig af egen kraft uden unødig indblanding fra voksne (Christensen, 2008; Gjerløff et al., 2014; Korsgaard et al., 2017, s. 275).

Reformpædagogikken var en del af en større reformbevægelse, der tog fart i starten af det 20. århundrede, og som også rummede andre elementer, der fokuserede på individuel frihed, demokrati, sundhed og rettigheder. Centralt i reformpædagogikken stod opgøret om skolen, der blev anset for at begrænse barnets udfoldelse og naturlige virkekraft. Reformpædagogerne kritiserede således både skolens indretning og undervisningsmetoder, der på dette tidspunkt bestod af overhøringer samt af en helt ny undervisningsform: klasseundervisningen ${ }^{3}$.

Kritikken af klasseværelsets indretning rettede sig imod de lange rækker af faste pulte, hvor bord og bænk var tømret sammen, hvilket reformpædagogerne mente hæmmede elevernes frihed, individualitet og virketrang. Til forskel herfra skulle skolen ifølge reformpædagogerne fungere som en 'hjemlig base' (Nørgaard, 1977). I de frie klasser $i$ Vanløse betød det, at lærerne opløste det traditionelle undervisningslokale til fordel for en indretning med løse borde og stole, der kunne stilles sammen i grupper.

I klasserne blev drenge og piger undervist sammen, hvilket på dette tidspunkt var meget usædvanligt. Endvidere fraveg lærerne de gængse principper for undervisning, der fokuserede på et fastlagt pensum og overhøring af eleverne, og introducerede $i$ stedet det, vi i dag ville kalde 'emneorienteret undervisning'. I den dagbog, der er bevaret fra en af forsøgsklassernes lærere, finder man beskrivelser af, hvordan undervisningen i alle fag tog udgangspunkt i fælles oplevelser fra blandt andet udflugter i naturen (gengivet i Henriksen \& Nørgaard, 1983). Der er her tale om en forløber for undervisningsformer, som i dag er helt almindelige i den danske folkeskole, men som i midten af 1920'erne var radikalt nytænkende.

Under de friere former kunne lærerne iagttage, hvordan eleverne arbejdede forskelligt: Mens nogle foretrak at arbejde alene, sluttede andre sig sammen i par eller grupper af forskellig størrelse i det omfang, opgaven krævede det (ibid.). Her var der ikke tale om formaliseret gruppearbejde, men om 'naturligt opståede' arbejdsgrupper. Eftersom man manglede egentlige pædagogiske principper, fokuserede lærerne

${ }^{2}$ Forsøgsordningen omfattede som udgangspunkt to af de 1. klasser, der startede i 1924 . Herefter blev der løbende startet forsøgsklasser, således at der var ti i 1928, da forsøgsordningen blev lukket (Nørgaard, 1977, s. 66).

${ }^{3}$ Klasseundervisningen blev introduceret i Danmark af Ernst Kaper (Kaper, 1902). Kapers introduktion til klasseundervisningen har haft en væsentlig placering i den danske læreruddannelse langt op i det 20. århundrede. 
fortrinsvis på 'den gode tone', der forudsatte, at elevene havde lært hensyntagen allerede inden mødet med skolen.

Hensyntagen og referencer til 'den gode tone' er ligeledes bærende i andre beskrivelser af gruppearbejdet fra denne periode. Grupperne skulle være det forum, hvori barnets individualitet og sociale og etiske forståelse formede sig til dets personlighed, som det udtrykkes af den samtidige tyske pædagog Peter Petersen, der var blandt inspirationskilderne til skoleforsøgene: "Og det bliver den nye Kunst at udvikle den rette Fællesskabsfølelse baade i Skolen som Helhed og i de enkelte Grupper. Gruppen og saaledes også Haven skal være et Øvelsessted, hvor samtidig den individuelle Vilje og Samfundsfølelse formes" (Petersen, 1923, s. 57) ${ }^{4}$. Tilsvarende hedder det i en antologi om nordisk aktivitetspædagogik: "Grupplivet ger läreren mögligheter till en verklig social fostran" (Hammarstrand i Köhler, 1936, s. 215).

Som det fremgår, betragtes barnet a priori som et aktivt og socialt individ, der naturligt vil slutte sig sammen med andre i grupper. Gruppen blev det forum, hvori individualiteten mentes at få de bedste vilkår for vækst - på fællesskabets præmisser. I den tidlige reformpædagogik var der med andre ord tale om subjektivering til egen-aktivitet, hensyntagen og altruisme, ganske forskelligt fra 1970'ernes politiserede kollektivisme.

\section{Tidlige gruppeorganiseringer: Den indbyrdes undervisning}

Som det fremgår, var der tale om spontant opståede grupper i den tidlige reformpædagogik. Men heller ikke i starten af 1900-tallet var grupper fremmed for pædagogikken, og det er sandsynligt, at der siden skolens oprindelse har været anvendt forskellige former for gruppering af eleverne. Ikke mindst på skoler i tyndt befolkede områder, hvor børn af forskellig alder blev undervist sammen. Her har det været rationelt for læreren at gruppere eleverne efter alder og formåen samt at lade ældre/ dygtigere elever hjælpe de yngre/mindre dygtige i en form for integreret og elevdifferentieret undervisning. Her kan man dog ikke tale om et egentligt pædagogisk princip affødt og appliceret igennem lærerens bevidste pædagogiske overvejelser; snarere har det været affødt af lærerens behov for at få en rimelig struktur på undervisningen af en differentieret elevgruppe samt at spare på underviserkræfterne.

Første gang man møder principper om formaliserede gruppedannelser i dansk pædagogisk sammenhæng, er i den angelsaksiske undervisningsteknik, der betegnes Bell-Lancaster-metoden, og som i Danmark gik under navnet den indbyrdes undervisning (Drejer et al., 2014). Metoden var udformet i Storbritannien (bl.a. Indien) i

\footnotetext{
${ }^{4}$ Hos Petersen er der tale om aldersintegreret undervisning, hvor eleverne blev inddelt i tre grupper: undergruppen, mellemgruppen og den ældste gruppe, der hver især blev underinddelt i grupper alt efter, hvilken opgave der skulle løses. Der har således været en vis alders- og kompetencemæssig spredning i grupperne. Dette princip har formentligt været bærende i tyndt befolkede områder, hvorfor det er sandsynligt, at dette også har været tilfældet i den nordiske aktivitetspædagogik. Til forskel herfra synes de frie klasser $i$ Vanløse at have været aldersmæssigt relativt homogene.
} 
starten af 1800-tallet efter militært forbillede og med henblik på optimering af skoleundervisning for fattige børn fra den hastigt voksende arbejderklasse. Herfra spredte den sig til resten af Europa.

I Danmark blev den indført ved kongelig forordning på første skoleår i alle landets skoler i 1822. Dette foregik i forlængelse af vedtagelsen af Anordning for Almue-Skolevcesnet i 1814, hvormed landet havde fået sin første lov om seks års almen skolegang for alle landets børn. Skoleloven blev mødt med modstand, ikke mindst på landet hvor familierne havde brug for børnenes arbejdskraft og derfor anså skolegang for unødvendigt tidsspilde. Da nationen samme år blev ramt af statsbankerot, blev loven yderligere udfordret af manglende økonomiske ressourcer (Drejer et al., 2014). Den indbyrdes undervisning blev anset for en undervisningsmetode, der gjorde det muligt at løfte den store opgave med at give alle landets børn de mest basale kundskaber på kortest mulig tid og med brug af færrest mulige lærerkræfter. Derfor blev der igennem visitation af kirkens øverste myndighed ført omhyggeligt tilsyn med, at metoden blev benyttet. Hvis læreren fraveg dette, kunne konsekvensen være afskedigelse (Drejer et al., 2014, s. 140).

Industrialiseringen igennem 1800-tallet betød en væsentlig befolkningstilvækst i byerne, hvilket pressede skolerne og efterhånden førte til flere og aldersordnede klasser (Gjerløff \& Jacobsen, 2013, s. 319). Men indtil skoleloven 1899 var skoleelever ikke som udgangspunkt inddelt i skoleklasser efter alder. I stedet var organisationsprincippet, at alle elever befandt sig i ét og samme rum, og/eller at en del af eleverne (fx de ældste) gik i skole om formiddagen, mens andre (fx de yngste) gik i skole om eftermiddagen. Det betød, at der kunne være en stor gruppe børn, der trods forskel i alder og niveau skulle undervises samtidigt ${ }^{5}$.

Kort fortalt gik den indbyrdes undervisning ud på, at eleverne ${ }^{6}$ blev inddelt i tre kategorier: hjælper, bi-hjælper og lærlinge. Lærlingene blev dernæst inddelt i grupper, der stående ved tavler blev undervist/overhørt af bi-hjælperne. I praksis ville eleverne blive organiseret i mange sådanne grupper omkring mange tavler, hvor de udvalgte elever (bi-hjælpere) underviste og overhørte de mindre dygtige. Hjælperen var en dygtigere (typisk en ældre) elev, der havde til opgave sammen med læreren at overvåge samtlige grupper samt at gå rundt mellem grupperne og sikre, at alt foregik, som det skulle. Eleverne var ikke alene inddelt i grupper; alle fik tildelt et nummer, der markerede den enkeltes placering i klassens hierarki vurderet ud fra dygtighed og flid.

Undervisningen fulgte et militaristisk stramt skema. Således beskriver provst J. Nissen metoden i 1902:

\footnotetext{
${ }^{5}$ Drejer et al. anfører, at der var 170 elever i en skole i Horsens, mens der kunne være væsentligt færre i mindre tæt befolkede områder (Drejer et al., 2014, s. 144).

${ }^{6} \mathrm{På}$ dette tidspunkt blev drenge og piger generelt undervist hver for sig i drenge- og pigeskoler eller drenge- og pigeklasser. I tyndt befolkede områder kunne det dog være nødvendigt at have skoler med både drenge og piger. I givet fald ville drengene blive samlet i den ene side af rummet og pigerne i den anden. I det omfang at forældrene havde råd, ville pigerne blive undervist hjemme.
} 
I de approprierede Bestemmelser var Fremgangsmaaden angivet indtil de mindste Enkeltheder, og Tiden var nøje afmaalt. Eksempelvis anføres Timeinddelingen om Eftermiddagen fra Normalskolens 1ste Klasse: Alle opstilles Kl. 4.16, efterses, formeres Læseskole 4.20; der læses indtil 5; Læseskolen opløses indtil 5.2; der formeres Skriveskole og begyndes med Skrivning 5.10; der skrives indtil 5.50; Skriveskolen opløses indtil 5.52; der gaas ned i 10 Minutter indtil 6.2; alle staa opstillede igen 6.3; der formeres Regneskole, og Regningen begynder 6.10; der udtages til Geografi og Forstandsøvelser 6.50, de øvrige vedblive at regne; Geografi, Forstandsøvelse og Regning indtil 7.5; Opløsning i 2 Minutter indtil 7.7; alle staa opstillede til at gaa 7.7; Bebrejdelse, Ros og Bøn i 8 Minutter indtil 7.15; alle gaa hjem 7.15. (Nissen, 1902, s. 150 ff.)

Interaktionen mellem lærer og elev var begrænset til enstavelsesord og stød i en signalpibe (fløjte). Kunne en elev ikke svare korrekt, blev han rykket en plads ned i klassens hierarki. Egentlig pryglestraf var ikke accepteret, da det forstyrrede undervisningen. I stedet anbefalede man at lade de formastelige knæle til skue for de øvrige elever (Drejer et al., 2014, s. 141; Høybye-Nielsen, 1969;).

Om end Nissen anfører, at metoden i 1833 var indført på 2.110 af landets 2.460 skoler, viser samtidige visitationsrapporter, at der har været mange skoler, hvor den har været fraveget i betydelig grad (for en oversigt se Høybye-Nielsen, 1969): Dels egnede den sig bedst til skoler med mange elever, hvilket kun var muligt i byerne, dels var den dyr at iværksætte, da den krævede, at skolen anskaffede et betragteligt antal (flere hundrede) tavler til brug for undervisningen.

Ifølge samtidige vurderinger var fordelen ved metoden, at den både opdragede eleverne til lydighed, og at den i et vist omfang kunne praktiseres af selv udygtige lærere ((Drejer et al., 2014; Høybye-Nielsen, 1969). Metodens stramhed og det at en del af underviserarbejdet var overladt til eleverne, betød, at lærerens kompetencer i bedste fald kom til at spille en mindre rolle. Imidlertid fremgår det af visitationsrapporterne, at metoden oftest blev benyttet af yngre veluddannede lærere, mens 'lærerens uduelighed' eller 'skolerummets uegnethed' oftest i visitationsrapporterne nævnes som årsagen til, at metoden ikke var indført på en skole. Dertil kom, at metoden har virket latterlig i de meget små skoler i de tyndt befolkede områder på landet (Høybye-Nielsen, 1969, s. 57 ff.).

Ikke desto mindre kom den indbyrdes undervisning til at stå som et symbol på skolens status som et sted, hvor fremskridt og orden trivedes (Høybye-Nielsen, 1969, s. 60). Dette til trods for at den i samtiden blev udsat for kritik fra blandt andet N.F.S. Grundtvig og Chresten Kold, der særligt var kritiske overfor de mange regler og mangel på 'frihed, liv og naturlighed' (Drejer, 2014, s. 62). Det er muligt, at denne kritik har bidraget til, at ordningen allerede blev ophævet igen i 1850, og normalskolen ${ }^{7}$ blev lukket i 1865, hvorefter metoden gradvist blev udfaset landet over (Nissen, 1902, s. 164). Dette til fordel for overhøringer samt efter århundredeskiftet Kapers klasseundervisning. Imidlertid foreligger der vidnesbyrd om, at den indbyrdes undervisning har været praktiseret af gamle lærere så sent som i 1950'erne (Høybye-Nielsen, 1969, s. 65).

${ }^{7}$ Sølvgades Kaserneskole i København, der fungerede som metodens idealskole. 
Denne anvendelse af grupper i undervisningen hviler på en forståelse af disciplin som grundsten i den dannelse, som skolen skulle bibringe børnene. Omvendt har det formentlig været ret begrænset, hvad eleverne har tilegnet sig rent fagligt, ligesom der ikke har været plads til nogen form for individualitet, kreativitet eller spontanitet. Og uanset metodens stramhed og lærernes, hjælpernes og bi-hjælpernes evne til at opretholde disciplin, er det ikke vanskeligt at forestille sig, at der har været en nærmest infernalsk larm i et skolerum med indbyrdes undervisning blandt 100 elever.

Som det fremgår, lægger anvendelsen af grupper i indbyrdes undervisning op til subjektivering til indordning, disciplin, fedteri og konkurrence; alt i alt en subjektivering, der er meget forskellig fra de måder, hvorpå grupperne i den progressive pædagogik tænktes at subjektivere til egen-aktivitet, individualitet og altruistisk dannelse, og grupperne i projektpædagogikken blev benyttet med henblik på subjektivering til kritik, kollektivisme og deltagerstyring.

\section{Tilbage til strukturen: Cooperative Learning}

Umiddelbart kan den indbyrdes undervisning med sin stramhed og disciplin synes meget forskellig fra senere måder at bruge grupper på i pædagogikken, sådan som det fremtræder i såvel den tidlige reformpædagogik som projektpædagogikken. Imidlertid kan man hævde, at der er ligheder mellem metodens stramhed og nyere tids interesse for undervisningsteknologier som blandt andet Cooporative Learning (CL), der fandt vej til Danmark i starten af 2000'erne og i dag praktiseres i de danske skoler sideløbende med projektpædagogikken.

Som udgangspunkt dækker betegnelsen cooperative learning i den angelsaksiske verden en række forskellige tilgange til læring i grupper (se fx Gillies, 2007). Fælles for dem er, at der arbejdes med en væsentlig højere grad af struktur end den, der igennem en årrække var indarbejdet i gruppearbejdet i Danmark (Wahlgren, 2012, s. 57). En af de mest indflydelsesrige repræsentanter for tilgangen er Spencer Kagan ${ }^{8}$, der siden midten af 1970 'erne har udarbejdet CL som en række generiske strukturerer, der er indholdsmæssigt tomme, og derfor kan benyttes i forbindelse med mange forskellige typer indhold: "The structural approach to cooperative learning is based on the creation, analysis, and systematic application of structures, or content-free ways of organizing social interaction in the classroom. Structures usually involves a series of steps, with proscribed behavior at each step" (Kagan, 1989, s. 12). I en artikel fra 2011 nævner Kagan selv 200 forskellige strukturer. Et eksempel er 'Numbered Heads Together':

1. The teacher has students numbered, so that each student has a number: 1, 2, 3, or 4 ;

2. The teacher asks a question;

${ }^{8}$ I det følgende vil CL alene referere til Kagans tilgang. 
3. The teacher tells the students to 'put their heads together' to make sure that everyone on the team knows the answer;

4. the teacher calls a number $(1,2,3$, or 4$)$, and students with that number can raise their hands to respond (Kagan, 1989, s. 13)

I et andet eksempel sammenligner Kagan strukturen 'Three Step Interview' med en traditionel gruppediskussion (Kagan, 1989, s. 13):

\begin{tabular}{|c|c|}
\hline Group discussion & Three step interview \\
\hline \multicolumn{2}{|l|}{ Steps in the process } \\
\hline $\begin{array}{l}\text { 1) The teacher asks a low-consensus question } \\
\text { 2) Students talk it over in groups. }\end{array}$ & $\begin{array}{l}\text { 1) Students form two pairs within their teams of } \\
\text { four and conduct a one-way interview in pairs. } \\
\text { 2) Students reverse roles: interviewers become the } \\
\text { interviewees. } \\
\text { 3) Students round-robin: each student takes a turn } \\
\text { sharing information learned in the interview. }\end{array}$ \\
\hline \multicolumn{2}{|l|}{ Characteristics } \\
\hline 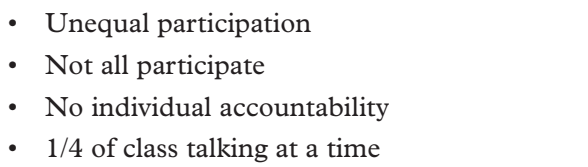 & $\begin{array}{l}\text { - Equal participation } \\
\text { - All participate } \\
\text { - Individual accountability } \\
\text { - } 1 / 2 \text { of class talking at a time }\end{array}$ \\
\hline
\end{tabular}

Grundlæggende bygger CL på en forståelse af, at læring kan opbygges trin for trin, og at varig læring forudsætter elevernes egen-aktivitet (Kagan, 1989). Som det fremgår af figuren ovenfor, er den største bekymring ved mere ustruktureret brug af grupper i pædagogikken, at der foregår en ujævn deltagelse, hvor ikke alle elever er aktive det meste af tiden. Af samme årsag kritiserer Kagan lærerstyret undervisning (Kagan, 2011).

Som det fremgår af den korte introduktion til 'Numbered Heads Together', er der meget i CL's stramme strukturer, der kan minde om den indbyrdes undervisning. I begge tilfælde udgør den stramme struktur så at sige lærerens sikkerhed for at undgå at begå fejl i sin undervisningspraksis, og læreren kan samtidig udadtil legitimere undervisningsarbejdet. Men hvor argumentationen i 1800-tallet primært fokuserede på disciplinering til lydighed samt minimering af ressourceforbrug, hentes argumenterne for CL i hjerneforskning og neuropsykologi: "Fremskridtet i aktive hjerneskanninger under arbejde og computerkraft har i forening frembragt en dybtgående forståelse af hjernestrukturer og hjernefunktioner [...] Det er nu meningsfuldt at tale om 'hjerne-venlig' undervisning" (Kagan, 2011, s. 41).

Om end der er ligheder mellem CL og indbyrdes undervisning, er der med andre ord også væsentlige forskelle, ikke mindst i argumentationen for metoderne. Derudover vil der i praksis være tale om væsensforskelle $\mathrm{i}$ det indhold, de to tilgange benyttes til. Mens den indbyrdes undervisning fokuserede på et meget begrænset indhold, er de 
spørgsmål, eleverne stilles overfor i CL i dag, mere komplekse og kan varieres med stigende krav. Men ikke desto mindre vil der også i CL være tale om en klart afgrænset og af læreren defineret opgave, hvorfor der levnes relativt lille rum for kreativitet og individualitet (Wahlgren, 2012). Hensigten med CL er, at eleverne internaliserer strukturerne, sådan at de gnidningsfrit kan indgå i samarbejder på måder, der fremmer deres individuelle læring.

Her er der tale om subjektivering til et lærende subjekt, hvor gruppen alene har til formål at danne rammen om individets læring. Med andre ord er der tale om subjektivering til individuelt lærende, hvilket er meget forskelligt fra den måde, hvorpå kollektivet i projektpædagogikken var selve formålet med gruppen og fra reformpædagogikkens subjektivering til egenaktivitet og hensyntagen. Dog er der i såvel CL som i reform- og projektpædagogik tale om subjektivering til et aktivt lærende individ, hvilket er meget forskelligt fra den indbyrdes undervisnings subjektivering til indordning og konkurrence.

Det skal her bemærkes, at eleverne i den skole, Kagans metode retter sig imod, typisk er inddelt i klasser efter alder. Det betyder, at deres kompetenceniveau forventes at være stort set ens, hvilket kan være en af årsagerne til, at 'uens deltagelse' betragtes som et problem, som CL-strukturen har til formål at eliminere. Til forskel herfra fremhæves inhomogen deltagelse ikke som problematisk i hverken reformpædagogikken eller den indbyrdes undervisning. I begge tilfælde har det vel snarere været betragtet som en lærings- og undervisningsmæssig fordel.

\section{Grupper, klasser og skolerum}

Som det fremgår, er der tale om fire meget forskellige tilgange til grupper i pædagogikken, ikke alene i form, men også i de subjektiveringsmuligheder, de åbner og lukker for deltagerne. Med i disse overvejelser hører også spørgsmålet om, hvor tilgangene praktiseres - med andre ord spørgsmålet om rum.

Den indbyrdes undervisning var primært tiltænkt undervisning af store grupper af elever - i mange tilfælde over 100 - i samme lokale (Drejer et al., 2014). Her var der ikke tale om interaktion i gængs forstand, men derimod om reproduktion ud fra en stramt tilrettelagt tidsplan. Som det fremgår, var de store grupper ikke usædvanligt i større byer, mens skolerne på landet var langt mindre børnerige, hvorfor metoden hverken var velegnet eller økonomisk rentabel. Vilkårene i landsbyskolen har lagt mere op til at gruppere eleverne efter kompetencer og lade dem hiælpe/undervise hinanden i løsere strukturer og en form for alders- og kompetenceintegreret undervisning (Gjerløff \& Jacobsen, 2013, s. 319).

Mens den indbyrdes undervisning, grupperingerne til trods, har været ganske fjernt fra det, vi i dag forbinder med 'gruppearbejde', har undervisningen på landet haft større lighed med det, der blev praktiseret i reformpædagogikkens skoleforsøg og senere generelt i den danske folkeskole. I de reformpædagogiske skoleforsøg var skolerummet således mere lig det, vi i dag forbinder med et klasselokale, og gruppen 
af elever mere lig det, vi i dag forbinder med 'en skoleklasse' - dvs. ca. 30 børn uden kønsopdeling. Rum indrettet med løse borde og stole muliggjorde fleksibilitet i undervisningen samt mulighed for interaktion - i et vist omfang på elevernes præmisser. Men bortset fra udflugter og 'legemsøvelser' har al undervisning, også arbejdet i de mindre grupper, foregået i dette lokale.

Med projektpædagogikken stilles der krav til gentænkning af klasserummet, hvilket i Danmark sker med etableringen af RUC, der indrettes med mange mindre grupperum og kun få store undervisningslokaler. Denne måde at opbryde det igennem 100 år velkendte klasserum på er sidenhen diffundereret over i alle andre dele af undervisningssektoren: de fleste danske klasselokaler er i dag møbleret på måder, der muliggør fleksibilitet i undervisningen, der er etableret grupperum, og skolernes gangarealer er indrettet, sådan at der er arbejdsmuligheder for mindre grupper. På denne vis er rammerne for CL på plads.

Disse forskelle i rammerne for grupper i skolen har væsentlig betydning for subjektiveringen: Mens den indbyrdes undervisning med de store rum, store grupper elever og faste rammer subjektiverer til underkastelse, stiller grupperum og fleksible rammer krav til fleksibilitet og selvforvaltning (Fendler, 2001). Dertil kommer, at der er forskel på, hvorvidt der er tale om aldershomogene eller aldersheterogene grupper. De bevidst heterogene grupper i den indbyrdes undervisning og det i tilgangen indbyggede princip om hierarki kan således forstærke såvel konkurrence som underkastelse. Til forskel herfra, har CL-strukturerne i nutidens aldershomogene grupper blandt andet til formål at sikre, at alle deltager i samme omfang.

Mens skolen i dag generelt er organiseret omkring aldershomogenitet, vil mange danske lærere - $\mathrm{i}$ lighed med de tidlige reformpædagoger - betragte en vis spredning i kompetencer i en gruppe som en dannelses- og læringsmæssig fordel. I heterogene grupper kan 'de dygtige' hjælpe 'de mindre dygtige', som det hed sig i reformpædagogikken (Köhler, 1936, s. 208-209). I givet fald kan gruppeprincippet måske endda spare lærerkræfter. Herved subjektiverer gruppearbejdet nogle som 'de dygtige' og andre som 'de mindre dygtige' om end på en anden måde end den indbyrdes undervisning. Undersøgelser af gruppearbejdet som element i projektpædagogikken viser, at dette er tilfældet (Christensen, 2013; Gregersen \& Mikkelsen, 2007).

\section{Opsamlende bemaerninger: subjektivering - til hvad?}

Som det fremgår, har der ligget meget forskellige rationaler bag de omtalte måder at inddrage grupper på i pædagogikken, ligesom det har haft forskellig effekt på subjektiveringen af deltagerne - lærere såvel som elever. Mens formålet med 1800-tallets indbyrdes undervisning var at afrette samt at bibringe eleverne et minimum af viden på kortest mulig tid og med brug af færrest mulige lærerkræfter, er formålet med CL at sikre, at alle elever deltager aktivt inden for de af læreren afstukne rammer (Wahlgren, 2012, s. 57). I modsætning til den indbyrdes undervisning stræbes der i CL mod subjektivering til metodisk stringens og individualitet. 
Også i den tidlige reformpædagogik stræbte man mod subjektivering af eleverne til individualitet og egen-aktivitet, men uden metode og med en anden betoning af frihed og altruistisk dannelse. Dermed adskilte subjektiveringstilbuddet sig markant fra den indbyrdes undervisning, der absolut ingen plads havde hverken til den enkelte elev eller til spørgsmålet om hensyntagen. I stedet var der tale om indordning og indbyrdes konkurrence.

Der er visse lighedstræk imellem reformpædagogikkens subjektiveringstilbud og det, man møder i 1970'ernes projektarbejde, men her med en drejning til fordel for kollektivisme, samfundskritik og udpræget deltagerstyring. Bjarne Wahlgren mener endvidere, at der er væsentlige forskelle i de kompetencer, der udvikles igennem projektpædagogikken og CL (Wahlgren, 2012, s. 59): Mens CL subjektiverer til (skematisk) strukturerede arbejdsformer, subjektiverer projektpædagogikken til selv at formulere problemet og organisere samarbejdet i gruppen. Dertil kommer subjektivering til at arbejde i grupper, hvilket - uanset graden af struktur - indebærer et krav om sociale kompetencer. Dette til forskel fra grupperne i den indbyrdes undervisning, hvor der reelt ikke var noget samarbejde, men derimod indbyrdes konkurrence eleverne imellem.

Mens projektpædagogikkens krav om kollektivt arbejde er relativt eksplicitte, kan CL's metodiske stringens, men indholdsmæssige tomhed, dels betyde, at form overskygger indhold, dels at undervisningen kommer til at hvile på lærerens (uudtalte) normer. Dermed bliver der tale om en ny variant af 'den skjulte lærerplan', hvor eleverne skal leve op til implicitte krav i en tilsyneladende fast struktur, der kræver, at eleverne underkaster og tilegner sig denne. Skolen har til formål at danne eleverne til selvstændighed, refleksion og samarbejde; elementer, der - såvel som kreativitet og individualitet - i CL overskygges af metodisk stringens.

Det er således muligt, at CL's stramme strukturer forskyder gængse forståelser af 'sociale kompetencer' til at være betinget af metodisk stringens. Dermed bliver det uklart, hvorvidt CL subjektiverer elever til at indordne sig den metodiske ramme på bekostning af såvel sociale kompetencer som individuel refleksivitet. Til forskel herfra er det normative grundlag for grupperne mere tydeligt i reform- og projektpædagogikken, hvorfor disse tilgange er klarere i relation til, hvilke former for subjektivering de bidrager til.

Artiklens fokus på subjektiveringen understreger, at pædagogiske tiltag ikke alene er rammer om det, der foregår i undervisningen, men medskabende af de individer, der deltager i den pågældende praksis. Som artiklen viser, er pædagogiske tiltag historisk forankrede og behæftede med tidens skiftende normer for, hvad der er rigtigt og forkert, korrekt og ukorrekt. Dermed sætter de også rammerne for, hvilke individer der inkluderes, og hvilke der ekskluderes i skolens praksis. Artiklen viser således, at det ikke er ligegyldigt, hvordan vi griber gruppearbejdet an, endsige hvilket normativt fundament det hviler på. Det har fundamental betydning for, hvilke individer, skolen danner. 


\section{Forfatterpresentation}

Gerd Christensen er lektor, ph.d., i pædagogik. Hun har igennem en årrække beskæftiget sig med pædagogisk psykologi og videnskabsteori, herunder særligt poststrukturalistiske tilgange samt gruppers funktion i pædagogikken.

\section{Referencer}

Andersen, N. Å. (1999). Diskursive analysestrategier. København: Nyt fra Samfundsvidenskaberne.

Borgnakke, K. (red.) (1984). Projektarbejde $i$ universitetsuddannelserne. Arbejdspapirer fra NFPF-seminar på RUC dec. 1983. København: NFPF.

Brødslev Olsen, J. (1995). Processen med problemet. En komparativ analyse af udviklingsprocesser $i$ problemorienteret projektarbejde. Aalborg: Aalborg Universitet.

Broström, S. (1974). Roskilde Universitetscenter. I: L. J. Muschinsky (red.). Forsøgskaninernes Oprør. København: Christian Ejlers' Forlag.

Christensen, G. (2008). Individ og disciplinering. Det padagogiske subjekts historie. Frederiksberg: Forlaget Samfundslitteratur.

Christensen, G. (2013). Projektgrupper - en undersøgelse af subjektiveringsmekanismer i gruppe- og projektarbejdet på universitetsniveau. Ph.d. afhandling. Emdrup: Aarhus Universitet.

Christensen, G. \& B. Hamre (2018). At tenke med Foucault. København: Unge Pædagoger.

Danziger, K. (1997). Naming the mind. How Psychology Found its Language. London: Sage.

Darling, J. \& S. E. Nordenbo (2003). 'Progressivism'. I: N. Blake, P. Smeyers, R. Smith \& P. Standish, The Blackwell Guide to the Philosophy of Education. Oxford: Blackwell Publishing.

Drejer, C. M. (2014). Kampen om eleven. Hvordan skoler skaber elever. København: Unge Pædagoger.

Drejer, C. M., J. E. Larsen \& N. Reeh (2014). Indførelsen af den indbyrdes undervisningsmetode i Danmark, dens konkrete udformning som disciplincer teknik $i$ klasselokalet og dens internationale variationer. http://www. uddannelseshistorie.dk/images/pdfer/2014-drejer-reeh-larsen.pdf (01.02.2019)

Fendler, L. (2001). Educating Flexible Souls. I: K. Hultquist. (ed.), Governing the Child in the New Millennium. New York: Routledge.

Frello, B. (1996). Projektpedagogik og udviklingsarbejde på RUC. UNIPÆD-projektet. Roskilde: Roskilde Universitetscenter.

Foucault, M. (2001). Talens forfatning. Nietzsche-genealogien, historien. København: Hans Reitzels Forlag.

Gillies, R. M. (2007). Cooperative Learning in Schools. I: R. M. Gillies (ed.), Cooperative Learning: Integrating Theory and Practice.Thousand Oaks, Calif.: Sage.http://dx.doi.org/10.4135/9781483329598.n1(07.01.2019)

Gregersen, C. \& Mikkelsen S. S. (2007). Ingen arme, ingen kager! En Bourdieu-inspireret praksisanalyse af skolens sociale sortering. København: Unge Pædagoger.

Gjerløff, A. K. \& Jacobsen, A. F. (2013). Da skolen blev sat $i$ system 1850-1920. Aarhus: Aarhus Universitetsforlag.

Gjerløff, A. K., Jacobsen, K., Faye, A., Nørgaard, E. \& Ydesen, C. (2014). Da skolen blev sin egen 1920-1970. Aarhus: Aarhus Universitetsforlag.

Granström, K. (red.) (2007). Forskning om lärares arbete i klassrummet. Forskning i fokus nr. 33. Stockholm: Myndigheten för skolutvikling.

Hammar Chiriac, E. (2003). Grupprocesser $i$ utbilding. En studie av gruppers dynamik vid problembaserat lärande. Disputats. Linköping: Linköping Universitet.

Hansen, E. (1997). En koral i tidens strøm. Frederiksberg: Roskilde Universitetsforlag.

Henriksen, S. \& Nørgaard, E. (1983). Vanløsedagbogen. København: Gyldendals Pædagogiske Bibliotek.

Hermann, S. (2007). Magt og oplysning: folkeskolen 1950-2006. København: Unge Pædagoger.

Høybye-Nielsen, E. (1969). Den indbyrdes undervisning i den sjællandske almueskole. I: Arbog for dansk skolehistorie. Hentet fra: http://www.uddannelseshistorie.dk/images/pdfer/a-1969-ernst-hoejbye-nielsen. pdf (01.02.2019)

Illeris, K. (1974). Problemorientering og deltagerstyring. København: Unge Pædagoger.

Illeris, K. (1978). Tendenser i 70'ernes pædagogik. I: U 90. Samlet uddannelsesplanlagning frem til 90'erne. Bd. 2. København: Undervisningsministeriet. 


\section{Gerd Christensen}

Jensen, H. T., Jacobsen, K. S., Ebbe, E. \& Clausen, N. S. (red.) (1997). RUC i 25 år. Frederiksberg: Roskilde Universitetsforlag.

Jæger, K. (red.) (2002). Projektarbejde og aktionsforskning. Aalborg: Aalborg Universitet. vol. 33.

Kagan, S. (1989). The Structural Approach to Cooperative Learning. I: Educational Leadership; Alexandria, Dec. 1989, 47, 4: 12 .

Kagan, S. (2011). En undervisningsrevolution - rationale og forslag til metoder. Kognition E Pcedagogik, nr. 81, 2011, 21. Årgang. København: Dansk Psykologisk Forlag.

Kaper, E. (1902). Den daglige undervisnings form. Kortfattet didaktik ud fra praksis. København: Gyldendalske Boghandel.

Keldorff, S. (1997). Noget om grupper - og om det at lykkes. I: P. Rasmussen, J. Seemann \& J. C. Tonboe, Egne veje. Festskrift til Per Salomonsen. Aalborg: Aalborg Universitetsforlag.

Keldorff, S. \& M. Nibe (1999). Når krage ikke søger mage. Et gruppepsykologisk eksperiment. Aalborg: Édition Edupax.

Key, E. (1902). Barnets Arhundrede. København: Gyldendalske Boghandels Forlag.

Kilpatrick, W. (1918). 'The Project Method' Teachers College Record, vol. XIX, no 4, september 1918.

Kristensen, H. J. (1997). En projektarbejdsbog. Fra 100 udviklingsarbejder om projektarbejde. København: Undervisningsministeriet, Folkeskoleafdelingen.

Korsgaard, O., KristensenJ. K. \& Jensen, H. S. (2017). Pcedagogikkens idehistorie. Aarhus: Aarhus Universitetsforlag.

Köhler, E. (1936). Aktivitetspeedagogik. Stockholm: Bokförlaget Natur och Kultur.

Nissen, J. (1902). Fra den indbyrdes Undervisnings Dage. Foredrag ved et Lcerermøde i Lunderskov d. 9. Maj 1902. hentet fra: https://r.search.yahoo.com/_ylt=AwrJ7JNIPFRcXQoAveBXNyoA;_ylu=X3oDMTEydWo5cm RuBGNvbG8DYmYxBHBvcwM5BHZ0aWQDQjY4OThfMQRzZWMDc3I-/RV=2/RE=1549053128/ $\mathrm{RO}=10 / \mathrm{RU}=$ https $\% 3 \mathrm{a} \% 2 \mathrm{f} \% 2 \mathrm{ftidsskrift.dk} \% 2$ ffraribeamt $\% 2$ farticle $\% 2$ fdownload $\% 2 \mathrm{f} 76660 \% 2 \mathrm{f} 110634 /$ $\mathrm{RK}=2 / \mathrm{RS}=\mathrm{AFhLfoWcZkAlAUJ8g5ZOXzaqLp0}-(01.02 .2019)$

Nørgaard, E. (1977). Lille barn, hvis er du? København: Gyldendals Pædagogiske Bibliotek.

Olsson, U., Petersson, K. \& Krejsler, J. (2018). Student centeredness and learning from a perspective of history of the present. I: E. Hultqvist, S.Lindblad \& T.S. Popkewitz (Eds.), Critical analyses of educational reforms in an era of transnational governance. Cham. Switzerland: Springer.

Petersen, P. (1923). Den nyeuropeiske skolebevcegelse. Fire foredrag af Dr. Phil. Peter Petersen. København: Fr. Jensens Bogtrykkeri.

Petersson, K., Olson, U. Popkewitz, T. S. \& Krejsler, J. (2016). Framtiden som styrning: en genealogisk betraktelse av det utbildningsbara subjektet och pedagogisk teknologi under det tidiga 2000-talet. I: G. Wärvik, C. Runesdotter, E. Forsberg, B. Hasselgren \& F. Sahlström (red.). Skola, lärare, samhälle: vänbok till Sverker Lindblad. Göteborg: Göteborgs Universitet.

Rasborg, F. (1968). Akademiske undervisningsformer. I: O.B. Thomsen (red.). Universitetspadagogiske studier. Odense: Odense Universitetsforlag.

Saar, M. (2002). Genealogy and Subjectivity. European fournal of Philosophy 10: 2. Oxford: Blackwell Publishers.

Sanden, E. \& P. Frederiksen (1997). Gruppearbejde i undervisningen. København: Frydenlund.

Sørensen, L. W. (1996). Gruppeprocessen i projektarbejdet. Udvikling af samarbejdsfærdigheder i projektorganiserede studier. I: Sørensen, L. W. (red.). Resultater fra uddannelsesevaluering på Aalborg Universitet. Metoder, konklusioner og metodeovervejelser. TNP-serien nr. 37. Aalborg: Aalborg Universitet.

Ulriksen, L. (1997). Projektpcedagogik - hvorfor det? Erhvervs- og voksenuddannelsesgruppen, Roskilde: Roskilde Universitetscenter.

Villadsen, K. (2006). Genealogi som metode - fornuftens tilblivelseshistorier. I: O. Bjerg \& K. Villadsen (red.), Sociologiske metoder. Fra teori til analyse $i$ kvantitative og kvalitative studier. Frederiksberg: Forlaget Samfundslitteratur.

Wahlgren, B. (2012). Internationale forskningsresultater og danske erfaringer. I: A. H. Jensen. Perspektiver på Cooperative Learning. København: Dafolo.

Walkerdine, V. (1984). 'Developmental psychology and the child-centered pedagogy: the insertion of Piaget into early education.' I: J. Henriques et al. (Ed.), Changing the Subject. London: Routledge. 